\title{
RENTAS Y EXIGENCIAS FEUDALES EN LA TIERRA DE LEMOS DURANTE LA BAJA EDAD MEDIA (SIGLOS XIV Y XV) ${ }^{1}$
}

\author{
FEUDAL INCOME AND REQUIREMENTS IN TIERRA DE LEMOS \\ DURING THE LATER MIDDLE AGES (14 ${ }^{\text {th }}$ AND $15^{\text {th }}$ CENTURIES)
}

\author{
José ANTONIO LÓPEZ SABATEL \\ Universidad de Santiago de Compostela
}

Resumen: El presente artículo pretende elaborar un análisis de las rentas y exigencias feudales presentes en la documentación bajomedieval de tres monasterios ubicados en la Tierra de Lemos: San Vicente de Pombeiro, Santa María de Ferreira y San Vicente del Pino (los dos primeros localizados en el actual municipio de Pantón y el tercero en el de Monforte de Lemos). A lo largo de este estudio, se distinguirán dichos derechos feudales en virtud de su origen: la propiedad de la tierra o el señorío, así como se señalarán los rasgos comunes y los particularismos de los mismos respecto a otras áreas de la geografía gallega para el mismo periodo.

Palabras clave: campesinado; señorío; renta feudal; Tierra de Lemos; Baja Edad Media.

\begin{abstract}
The present article seeks to carry out an analysis of the feudal income and requirements which are recorded in some documentation from the Later Middle Ages found in three monasteries situated in Tierra de Lemos: San Vicente de Pombeiro, Santa María de Ferreira and San Vicente del Pino (the two first ones are located in the council of Pantón and the third one in the council of Monforte de Lemos). Throughout this research, these feudal rights will be differentiated according to their origin: land property or domain, as well as, their common characteristics and their special features, which will be highlighted in connection with other parts of Galician geography during the same period.
\end{abstract}

Keywords: peasantry; domain; feudal income; Tierra de Lemos; Later Middle Ages.

\section{SUMARIO}

1. La naturaleza de la renta feudal.- 2. Renta derivada de la propiedad de la tierra.- 3. Renta derivada del reconocimiento del señorío.- 4 . Conclusiones.

\section{LA NATURALEZA DE LA RENTA FEUDAL}

El principal objetivo de este estudio es realizar un examen de la estructura y composición de la renta feudal en el seno del marco geográfico correspondiente a la Tierra de Lemos a lo largo de los siglos XIV y XV. Con este fin se ha procedido

${ }^{1}$ Abreviaturas utilizadas: $\mathrm{ACO}=$ Archivo de la Catedral de Orense; $\mathrm{AFP}=$ Archivo del Monasterio de Santa María de Ferreira de Pantón; AHN = Archivo Histórico Nacional; AHPO = Archivo Histórico Provincial de Orense; ASVM = Archivo del Monasterio de San Vicente del Pino de Monforte. 
a elaborar un análisis de la documentación perteneciente a los tres monasterios más significativos de esta comarca, dos de ellos (Santa María de Ferreira y San Vicente del Pino) localizados en el actual municipio de Pantón, y el tercero (San Vicente del Pino) en el de Monforte de Lemos. No obstante, esta labor de investigación adolecerá de las limitaciones cuantitativas y estadísticas características de las fuentes medievales en el ámbito gallego a la hora de precisar la determinación espacial de cada explotación aforada, así como la producción media de estas unidades de superficie. En consecuencia, ante la ausencia de estos datos, este estudio se orientará más desde una vertiente cualitativa, a describir tanto la constitución como la evolución de las diferentes exacciones y prestaciones feudales, así como sus particularismos en relación con otros espacios territoriales, que a clarificar la cantidad precisa de la totalidad de renta detraída respecto al bien aforado, elemento éste último imprescindible para poder determinar el montante íntegro de los ingresos señoriales derivados de la renta feudal y la repercusión de la misma en la economía campesina de la época.

Es sabido que uno de los rasgos más distintivos de las estructuras señoriales del norte de la Península Ibérica viene determinado por la complejidad, y el ámbito señorial gallego no es una excepción. La característica principal de la ordenación del poder señorial sobre el espacio explotado, viene originada por la confusión a la hora de abordar un enrevesado tejido de derechos señoriales, nacido de un laberinto de dominios superpuestos o yuxtapuestos entre sí. De este modo, el poder del señor en unos lugares deriva de la propiedad dominical, o del domino eminente y directo, según se utilice la terminología respectivamente de Estepa $^{2}$ o Clavero ${ }^{3}$, y en otros, del dominio señorial. Así, un señor puede tener propiedades en el seno de un señorío ajeno, mientras que en su propio dominio señorial ciertos bienes y derechos corresponden a otro señor en razón de su condición de propietario dominical, sin embargo, aunque el señor dominical no sea el señor del lugar, no quiere decir que no se atribuya la potestad de ejercer un cierto dominio señorial sobre los campesinos que trabajan sus tierras ${ }^{4}$. Esta tesitura se evidencia en la evolución del señorío monástico, que partiendo de la donación regia de un coto inmune, extendería sus dominios por medio de las donaciones pro anima, la incomunicación, y los contratos de compra-venta comunes a lo largo de toda la Edad Media ${ }^{5}$. En el ámbito territorial de este estudio, la dualidad entre lo dominical y lo señorial no es infrecuente, observándose en algunos contratos de aforamiento, la cesión de explotaciones monacales enclavadas en un distinto dominio señorial. Es el caso del monasterio de San Vicente de Pombeiro cuando afora diferentes heredades emplazadas en los cotos de San Esteban, Diomondi y Amandi, dominios señoriales pertenecientes, el primero, al monasterio de San Esteban de Ribas de Sil, y los dos últimos, al obispado de Lugo ${ }^{6}$. Misma situación se manifiesta en el monasterio

\footnotetext{
${ }^{2}$ Carlos EsTEPA DíEZ, Formación y consolidación del feudalismo en Castilla y León en VV.AA., En torno al feudalismo hispánico-I Congreso de Estudios Medievales, Ávila, 1989, pp. 157-256/161163.

${ }^{3}$ Bartolomé Clavero, Mayorazgo. Propiedad feudal en Castilla (1369-1836), Madrid, 1974, pp. 4-5.

${ }^{4}$ Ignacio ÁlVAREZ BoRge, Sobre las relaciones de dependencia en las behetrías castellanas en el siglo XIII: hipótesis a partir del caso de Las Quintanillas en Señorío y feudalismo en la Península Ibérica (ss. XII-XIX), III, (Esteban SARASA SÁNCHEZ y Eliseo SERRANO MARTín, eds.), Zaragoza, 1993, pp. 225-240/239.

5 José García Oro, Galicia na Baixa Idade Media. Igrexa, señorío e nobreza, A Coruña, 1999, p. 12.

${ }^{6}$ ACO, Monástica, Pombeiro, núm.3868, 4428, 4576 y 5031; Manuel LuCAS Álvarez y Pedro LuCAS DomíngueZ, El priorato benedictino de San Vicenzo de Pombeiro y su colección diplomática en la Edad Media, A Coruña, 1996, pp. 192,253-254, 287-288 y 321-322.
} 
de Santa María de Ferreira, con un gran porcentaje de su patrimonio disperso entre los cotos de Pantón, Moreda, Eiré, los Castillones e incluso en la villa de Monforte (señoríos todos del conde de Lemos), o en el gran número de propiedades, situadas en esta misma localidad, pertenecientes al monasterio de San Vicente del Pino ${ }^{7}$. A diferencia de otras comarcas gallegas, donde se establece una clara distinción entre propietario y titular de señorío, en correspondencia con las obligaciones demandadas ${ }^{8}$, en la Tierra de Lemos la cesión del dominio útil, no sólo conlleva el pago de una renta de carácter económico y compensatoria derivada del dominio directo, sino también, la satisfacción de unos derechos de naturaleza típicamente señorial entre los que hay que destacar ciertas prestaciones como la derechura y la luctuosa. La explicación de esta particularidad se remonta a la misma aparición de los foros, pieza angular de la pretensión señorial de extender, más allá de los límites territoriales del coto, las relaciones señoriales inherentes a aquél. De esta forma, los señores estarían en disposición de exigir, aparte de un censo, un reconocimiento de señorío, que equiparase en una misma condición de sumisión tanto a los foreros como a los habitantes del coto?

Es en consecuencia, la estructura del foro, entendido éste como una extensión de los derechos señoriales, la que determine la naturaleza de la renta a satisfacer por el campesinado. Desde una perspectiva formalista, se podrían distinguir dos tipos de detracciones: una de carácter territorial, y otra en función del desempeño de la autoridad pública ${ }^{10}$. Ante tal disposición, podría ser válida la tesis de Moxó y su división teórica entre renta procedente del señorío territorial y del jurisdiccional ${ }^{11}$. La cuestión aquí, es que el receptor del foro, no paga la renta principal del contrato en reconocimiento de un señorío territorial, ya que como ya se apuntó, en muchas ocasiones el forista no es el titular de dicho señorío, sino por el dominio útil de una propiedad dominical ${ }^{12}$, siendo la naturaleza de esta exacción más económica que señorial. ${ }^{13} \mathrm{La}$ otra tipología de tributos y prestaciones, si que comportan una idiosincrasia señorial, con reminiscencias del ámbito jurisdiccional de la tierra acotada que los generan. Sin embargo, la dificultad de su clasificación teórica viene dada por la confusión originada, no sólo por su nulo cometido en el ejercicio del poder público, sino en la imposibilidad en ocasiones, como se podrá apreciar en el transcurso de este estudio, de poder desligar algunas de estas exigencias de su carácter territorial. De este modo, y en coherencia con lo anteriormente referido, el esquema metodológico que se utilizará de aquí en adelante, para facilitar una aproximación a los diferentes tipos de rentas y prestaciones, es el que viene formulado por los contratos forales: una renta derivada de la propiedad de la tierra y otra procedente del reconocimiento de señorío.

${ }^{7}$ Además de ciertas posesiones localizadas en los cotos de Pantón y Moreda que al igual que la villa de Monforte quedan bajo la titularidad señorial del conde de Lemos. Todas ellas presentes en la relación de bienes efectuada por el cenobio en 1417. AHN, Sección clero, Carpeta 1198, n 17.

${ }^{8}$ Carlos. A. DeAño Gamallo, Rivadavia y su comarca en la Baja Edad Media, A Coruña, 2004, p. 145.

${ }^{9}$ María del Carmen Pallares Méndez, Los cotos como marco de los derechos feudales en Galicia durante la Edad Media (1100-1500), "Liceo Franciscano", 31(1978), pp. 201-225/224-225.

${ }^{10}$ Maria del Carmen PALlares MÉndEZ, El monasterio de Sobrado: un ejemplo del protagonismo monástico en la Galicia medieval, La Coruña, 1979, pp. 97-100.

${ }^{11}$ Salvador de Moxó, Los señoríos. Estudio metodológico en Actas de las I jornadas de metodología aplicada de las ciencias históricas, Vigo, 1975, pp. 163-173/171.

${ }^{12}$ Ermelindo PORTEla SILVA, La región del obispado de Tuy en los siglos XII a XV. Una sociedad en la expansión y en la crisis, Santiago de Compostela, 1976, p. 153

${ }^{13}$ Eleutino ÁlVAREZ ÁlvAREZ, Las exigencias señoriales en la Galicia meridional a través de la duración y la renta de los contratos de foro (1340-1450), "Cuadernos de estudios gallegos", 34 (1983), pp. 117-152/117. 


\section{RENTA DERIVADA DE LA PROPIEDAD DE LA TIERRA}

Partiendo de una terminología estrictamente jurídica, se puede explicar el foro como un "contrato en el que el propietario de una cosa inmueble se obliga a ceder a otro su dominio útil para siempre, o por un término limitado, reservándose en ella algunos derechos, y especialmente el de percibir cierta pensión anual en representación del directo que retiene"14. En la época que nos ocupa tal definición, como es obvio, es acreedora de ciertos matices. En primer término, la identificación del titular del dominio como el señor, que reservándose el dominio eminente de la propiedad, cede a su vasallo el útil o la explotación del mismo por un periodo variable estipulado en voces o generaciones. En segundo lugar, la exigencia de una renta principal de carácter económico y esencialmente agrario, determinada ya sea por una parte proporcional de la cosecha, fija en especie o monetaria, como compensación a la cesión del usufructo relativo al mencionado dominio. Por último, el pago de determinados servicios y tributos, debidos a la condición de vasallo que el forero tiene respecto al forista o señor ${ }^{15}$, es decir, una renta más que compensatoria, generada a raíz del reconocimiento del señorío por parte del receptor del contrato foral.

Esta armonización de exacciones de diferente naturaleza, se puede colegir según Villa-amil y Castro en el origen mismo del foro, entendiendo que su configuración definitiva parte de una progresiva unificación en un todo, tanto de las exigencias derivadas de la propiedad de la tierra, como de aquellas procedentes del dominio de los hombres ${ }^{16}$. De hecho, la misma palabra foro desde una perspectiva etimológica, en torno a los siglos XII y XIII, pasó de designar las diferentes las rentas y prestaciones que el vasallo debía de satisfacer a su señor, tanto como propietario este último de la tierra como en reconocimiento de su poder superior sobre los habitantes de sus dominios, a denominar todos los contratos agrarios que comprendían tales exacciones ${ }^{17}$.

De las mencionadas exigencias circunscritas en el seno del contrato foral, la que otorga el sentido principal al mismo, es aquella derivada de la cesión del usufructo de la propiedad, es decir, la renta de naturaleza económica que nace del dominio eminente del señor. Es sabido, que este tipo de rentas son articuladas por los grandes dominios siguiendo ciertas modalidades de detracción. Básicamente, éstas pueden ser exigidas mediante el pago de una cantidad proporcional de la cosecha, una cantidad fija de un determinado producto (renta en especie), o a través de una cantidad determinada en metálico (renta en dinero). De todas ellas, las más comunes en la mayor parte de la geografía gallega medieval, son las primeras. Una preeminencia de la renta producto que responde a dos factores primordiales: favorecer de una manera directa, sencilla y en la mayoría de las ocasiones económica, la provisión alimentaria de las diferentes instituciones eclesiásticas, y garantizar la recepción de una renta, mucho más estable que una moneda, susceptible de ser víctima de una depreciación propia de periodos inflacionistas ${ }^{18}$.

${ }^{14}$ José Castro Bolaño, Del Foro, "Boletín Judicial de Galicia", 45 (1857), p. 355.

${ }^{15}$ E. ÁlVAREZ, Las exigencias señoriales, pp. 117-152/117.

${ }^{16}$ José VILla-AmIL y CASTRO, Los foros de Galicia en la Edad Media: estudio de las transformaciones que ha sufrido en Galicia la contratación para el aprovechamiento de las tierras, Madrid, 1984, pp. 61 y ss. y 117.

${ }^{17}$ Faustino MARTÍNEZ MARTíNEZ, De verborum significatione: notas sobre las acepciones medievales de la voz foro, "Boletín do Museo Provincial de Lugo", 11 (2003-2004), pp. 247-264/258 y 261.

${ }^{18}$ María Luz Ríos RodríGuez, As orixes do foro na Galicia medieval, Santiago, 1993, pp. 87-88. 
De entre estas rentas en especie, las que se corresponden al pago de una cuota proporcional de la cosecha, son las que mejor se articulan bajo la premisa del férreo control ejercido por el monasterio sobre la producción de la gestión indirec$\mathrm{ta}^{19}$. El pan, el vino, y en el caso del monasterio de San Vicente de Pombeiro, las castañas, constituyen los productos básicos sobre los que recae la detracción de este tipo de renta. El análisis de su evolución, a lo largo de los siglos XIV y XV a través de la documentación monástica, da como resultado realidades bien diferenciadas. Si se estudian los datos procedentes de los contratos forales pertenecientes al monasterio de Pombeiro, se pone de manifiesto, a lo largo de las dos centurias bajomedievales, la preponderancia de la renta proporcional, respecto a las exigidas en dinero o cantidad fija de producto. Partiendo de una situación muy equilibrada del 51,28\%, en correspondencia con el resto de las rentas a requerir para el siglo XIV, su demanda da un salto cuantitativo importante en la primera mitad del siglo XV, al situarse en un $86,16 \%$, para descender en la segunda mitad de esta centuria a un porcentaje del $70,17 \%$. En cambio, en la colección diplomática de San Vicente del Pino, se percibe un desarrollo completamente diferente de esta renta que no supera el 28,56\% en la primera mitad del siglo XIV, iniciándose una línea descendente, que finalizaría con el $15,04 \%$ del montante total de las detracciones ya en la segunda mitad del siglo XV. En lo que respecta al monasterio de Santa María de Ferreira, si bien mantiene unos porcentajes relativos a la presencia de renta proporcional mucho más elevados en comparación con los referidos en los foros de su vecino de Monforte, es cierto que comparte con este último, la misma progresión descendente, un decrecimiento que se irá formulando desde la más alta cuota del $92,82 \%$ en la primera mitad del siglo XIV, hasta apenas el 18,75\% de la segunda mitad del siglo XV, pasando por los datos intermedios del 63,39\% de la segunda mitad del siglo XIV, y el 55\% de la primera mitad del XV.

\section{EVOLUCIÓN DE LA RENTA PROPORCIONAL}

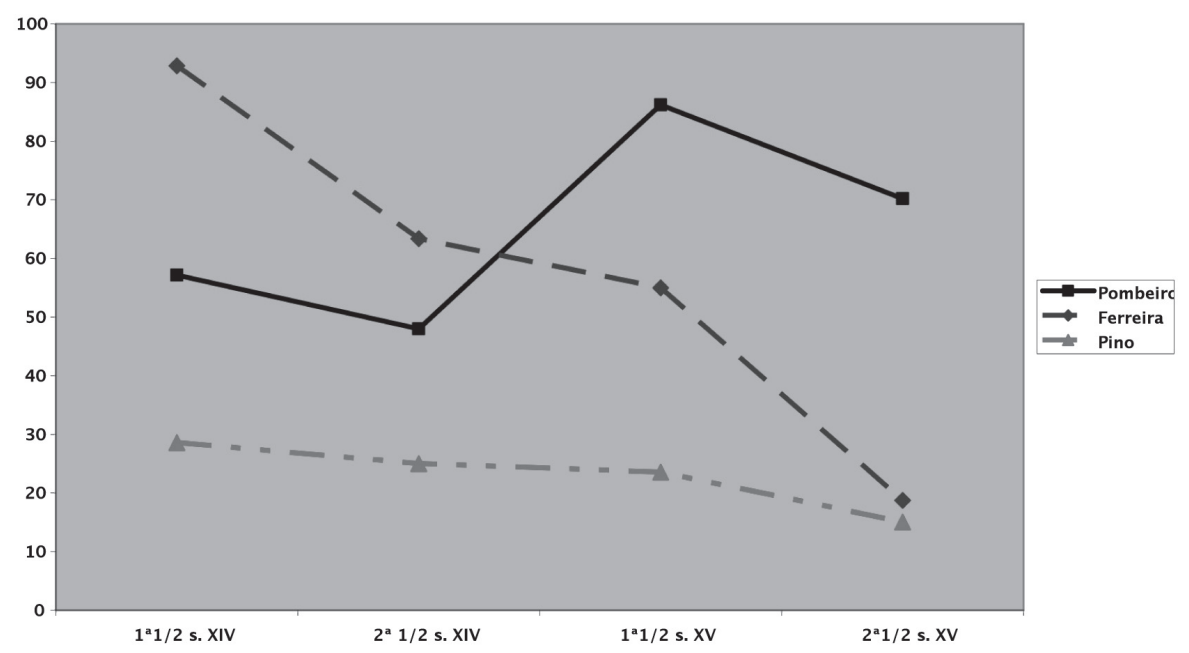

${ }^{19}$ María del Carmen SÁNChEZ CARrerA, El Bajo Miño en el siglo XV. El espacio y los hombres, A Coruña, 1997, p. 142. 
Este proceso deflacionista de los niveles de reclamación de renta proporcional de la cosecha, irá estrechamente ligado a un alza progresiva de las peticiones de renta fija en especie. De esta manera, y según los datos extraídos de la documentación de San Vicente del Pino, la presencia de renta fija en producto, no hace sino intensificarse al compás de los siglos bajomedievales. Así, si a lo largo del siglo XIV este tipo de detracción responde al $15,78 \%$ de todas las menciones relativas a rentas, en la primera y segunda mitad de la centuria posterior, su aparición se constata correlativamente en el $35,02 \%$ y el $46,32 \%$ del total. Esta coyuntura, es similar en el área de dominio del monasterio de Santa María de Ferreira donde, como en el caso anterior, las rentas derivadas de una cantidad fija de grano o vino, partiendo de un $7,14 \%$ durante la primera mitad del siglo XIV, inician una línea de progresión ascendente en el seno de las exigencias señoriales, a cuyo término se situarán en un porcentaje del $59,37 \%$, ya en la segunda mitad del siglo XV, atravesando fases del $21,94 \%$ y del $30 \%$ para la segunda y primera mitad de los siglos XIV y XV respectivamente. Tal como acontecía en la evolución de la renta proporcional de la cosecha, los parámetros de exigencia en lo que se refiere a las rentas fijas de producto correspondientes al monasterio de San Vicente de Pombeiro, se alejan de las líneas de la progresión ascendente ininterrumpida propias de los dos cenobios vecinos de la Tierra de Lemos. Aquí se puede observar como, si bien la presencia de renta fija tuvo cierto protagonismo a lo largo del siglo XIV, al cubrir una proporción del 33,32\% de las exacciones derivadas de la propiedad territorial, una vez que comienza el siglo XV, esta cifra, coincidiendo con el auge de las demandas de una cuota proporcional de la cosecha, cae a un $9,16 \%$, para finalmente instalarse en un aún reducido 16,79\%, muy alejado de los niveles de exigencia de Santa María de Ferreira y San Vicente del Pino para este periodo.

Es bien conocido, que el protagonismo y los niveles de percepción de una forma u otra de pago, ya fuese en cantidad fija o proporcional de la cosecha, así como sus modificaciones, únicamente respondían a estrategias señoriales dirigidas a satisfacer sus intereses de la manera más beneficiosa posible, constituyéndose de este modo en indicadores de una coyuntura económica determinada ${ }^{20}$. No es de extrañar, que en momentos de inclemencia meteorológica, inestabilidad política y en consecuencia, malas cosechas, los rectores monásticos prefieran la estabilidad que proporciona la recepción de unas cantidades predeterminadas e inalterables, ante la insegura opción de un tanto por ciento de una cosecha sujeta a ser damnificada por cualquier variable externa ${ }^{21}$. Por otro lado, la exigua presencia de las rentas fijas, concernientes a la documentación de San Vicente de Pombeiro, se puede llegar a entender, propuesta ésta también válida en algunos contratos forales elaborados por los monasterios vecinos, como la reacción señorial originada a causa de la existencia de propiedades aforadas de escaso valor o ajenas a un asequible control monástico ${ }^{22}$.

\footnotetext{
${ }^{20}$ María Xosé RodríGuez GaLdo, Señores y campesinos en Galicia. Siglos XIV-XVI, Santiago de Compostela, 1976, p. 195.

${ }^{21}$ Marta GonzÁLeZ VÁzQueZ, El monasterio de San Julián de Samos en el siglo XIV (13251380): un análisis de la evolución de sus rentas, "Museo de Pontevedra", 44 (1990), pp. 621-642/632.

${ }^{22}$ M. LUCAS, P. LUCAS, El priorato benedictino, p. 42.
} 


\section{EVOLUCIÓN DE LA RENTA FIJA EN ESPECIE}

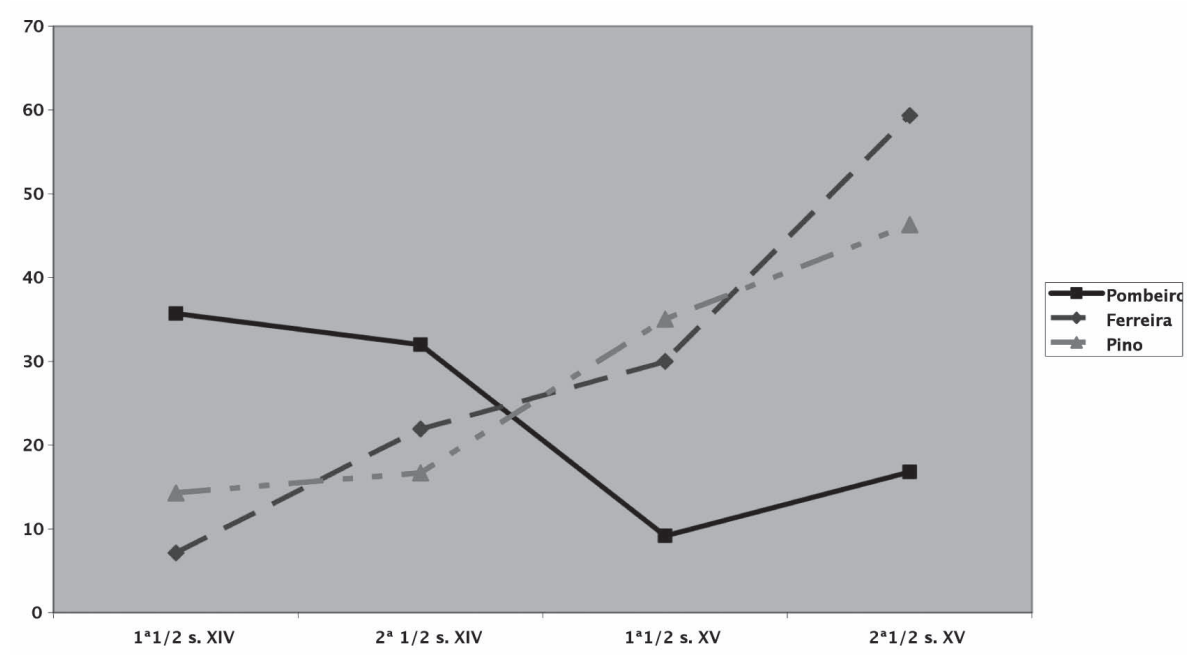

Otra política señorial, comúnmente aceptada en muchas regiones europeas para hacer frente a las primeras décadas de la crisis del siglo XIV, consistió en la transformación en numerario de los censos estipulados en especie ${ }^{23}$. Esta reacción señorial, también se puede observar en la región del obispado de Tuy, donde los bajos rendimientos agrarios impulsan a los señores a incrementar la exigencia de rentas en dinero, llegando las mismas incluso a aventajar en la segunda mitad del siglo XIV a las tradicionales rentas en especie ${ }^{24}$. Esta coyuntura, aunque no de una manera tan marcada, también es perceptible en el espacio geográfico que nos ocupa. Así, las rentas en dinero exigidas por San Vicente de Pombeiro, durante la primera mitad del siglo XIV, pasan de un porcentaje del $7,14 \%$, en relación con las reclamadas en especie tanto fija como proporcional, a un $20 \%$ para el resto de la centuria. Del mismo modo, en los dominios de Santa María de Ferreira, la renta en dinero y mixta en dinero y especie alcanzaría una proporción del $14,72 \%$ en la segunda mitad del XIV, cifra significativa ya que tales detracciones son inexistentes a lo largo de los primeros diez lustros del mencionado siglo. No obstante, hay que constatar una clara diferenciación en la línea de actuación en ambos ámbitos señoriales. En el área de dominio del monasterio de San Vicente de Pombeiro, la exigencia de una cuantía monetaria, especialmente en lo que se refiere a la última década de esta centuria, recae únicamente sobre explotaciones agrarias, de lo que se deduce una clara política señorial ante la difícil coyuntura económica del momento. Sin embargo, en el entorno del monasterio de Santa María de Ferreira, la totalidad de las rentas en dinero se requieren en compensación del usufructo de casas, en consecuencia tal detracción, estaría más vinculada a la naturaleza de los bienes aforados que a una decidida estrategia señorial. Pese a que se pueda dejar entrever, en un periodo marcado por el marasmo p. 427.

${ }^{23}$ Georges DuBY, Economía rural y vida campesina en el Occidente medieval, Barcelona, 1999,

${ }^{24}$ E. PORTELA, La región, p. 306. 
en la producción, un aumento de las exacciones exigidas en moneda, éstas ni mucho menos alcanzarían tales niveles como para amenazar, tal como acontecía en la región del obispado de Tuy, el predomino de las rentas en especie.

Ya en la primera mitad del siglo XV, los contratos forales suscritos por San Vicente de Pombeiro, como se señaló con anterioridad, muestran una decidida apuesta por las rentas proporcionales de la cosecha $(86,16 \%)$, y relegan a las rentas en dinero $(4,58 \%)$ y fijas en especie $(9,16 \%)$, a un papel más que secundario. Además, es necesario resaltar que el conjunto del reducido porcentaje de rentas en dinero, ya no gravan terrenos de cultivo, sino la posesión de casas, un solar destinado a la construcción, un molino y un puerto fluvial. En lo que respecta a Santa María de Ferreira se colige una propensión, al igual que sucedía con las rentas fijas en especie, a seguir una línea de progresión ascendente en lo relativo a la recepción de renta en dinero y mixta, estableciéndose una cuota al alza en relación con el resto de exacciones del $15 \%$ y $22,87 \%$ respectivamente para la primera y segunda mitad del siglo XV. Sin embargo, al igual que sucedía a partir de 1350, esta demanda de numerario estaría íntimamente vinculada con el carácter de los bienes aforados. De esta manera, las exacciones derivadas del usufructo de casas, bodegas y solares edificables, representarían el $55,5 \%$ y el $80 \%$ de la totalidad de las rentas en dinero para la primera y la segunda mitad del siglo XV correlativamente.

Un estudio particular, requiere la documentación contractual emitida por el monasterio de San Vicente del Pino, en relación con la detracción de la renta en dinero. Este cenobio, es el único de los tres estudiados, enclavado en un centro urbano y en consecuencia, tal como sucedía en la cercana ciudad de Ourense, cabría pensar en un mayor protagonismo de la renta monetaria ${ }^{25}$. Esta premisa, se cumple en las dos centurias bajomedievales. Así, en la primera mitad del siglo XV, su proporción se sitúa en un $35,03 \%$, frente al $35,02 \%$ de la renta fija, el $23,54 \%$ de la renta proporcional, y el $6,36 \%$ de la renta mixta. En los cincuenta años siguientes, la renta en dinero no sufre variaciones manteniéndose en un $34,07 \%$ de la renta exigida, no sucede lo mismo con la renta fija que se incrementa en un $46,32 \%$, a expensas de la reducción en la demanda de la renta proporcional en un $15,04 \%$ y mixta en el $4,46 \%$. Sería consecuente colegir, que esta relevancia de la renta en dinero, se debe al carácter urbano de unos foros formulados sobre aquellos bienes inmuebles, que por si mismos, no son nada idóneos para la producción en especie. Sin embargo, de las cincuenta y cinco menciones relativas a rentas en dinero para la primera mitad del siglo XV, veintiuna $(38,18 \%)$ corresponden a foros en los que se alude a casas, bodegas, casarellos y un solar edificable, y de estas veintiuna, ocho se refieren a casas a las que se adjuntan terrenos de cultivo (leira, terreno, viña, huerto y heredades). En relación con la segunda mitad de este siglo, la tendencia seguida con estos bienes inmuebles se acentúa, ya que de las sesenta y una referencias a rentas en dinero, solamente dieciocho $(29,50 \%)$ corresponden a este tipo de bienes, la mitad de los cuales están unidos a leiras, huertos, terrenos y heredades. Es por ello plausible argumentar, que la importancia dada por este monasterio monfortino a las rentas en dinero se deba, tal como sucedía con las rentas fijas en especie, más que a su carácter urbano, a una serie de decisiones destinadas a resguardar unos beneficios seguros, más allá de la inestable productividad de las propiedades aforadas. Esta política monástica, cobra gran relevancia a lo largo de las décadas en las que la crisis golpea con más virulencia. De esta manera, en la segunda mitad del siglo XIV, la renta exigida en numerario con siete menciones $(58,33 \%)$, se consolida como la principal frente al $24,99 \%$ y al $8,33 \%$ de las referencias relativas a rentas proporcionales y fijas. Otro fac-

${ }^{25}$ Anselmo LóPEZ CARreIRA, Ourense no século XV. Economía e sociedade urbana na Baixa Idade Media, Vigo, 1991, pp. 51-52. 
tor determinante, que favorece el aumento a partir de 1348, de la demanda monetaria, en especial en lo que respecta a San Vicente de Pombeiro y a San Vicente del Pino, es el relativo a la evolución de precios de la época. Mientras que en las fases de carestía, los precios agrícolas subían de manera desmedida, y tras un corto periodo de tiempo retornaban a su punto de partida, los precios de los productos manufacturados, en cambio, mantuvieron un crecimiento sostenido ${ }^{26}$. De ahí la necesidad de los rectores monásticos de mayor cantidad de dinero, para hacer frente a los gastos de los productos que consumían. No hay que olvidar tampoco, que una de las consecuencias de cualquier periodo de crisis, es el acaparamiento de moneda acuñada y su tesorización, así que una gran parte del dinero efectivo no entraba ni siquiera en circulación ${ }^{27}$, por lo que se hacían perentorias las detracciones en numerario para obtener unos activos mínimos.

\section{EVOLUCIÓN DE LA RENTA FIJA EN DINERO}

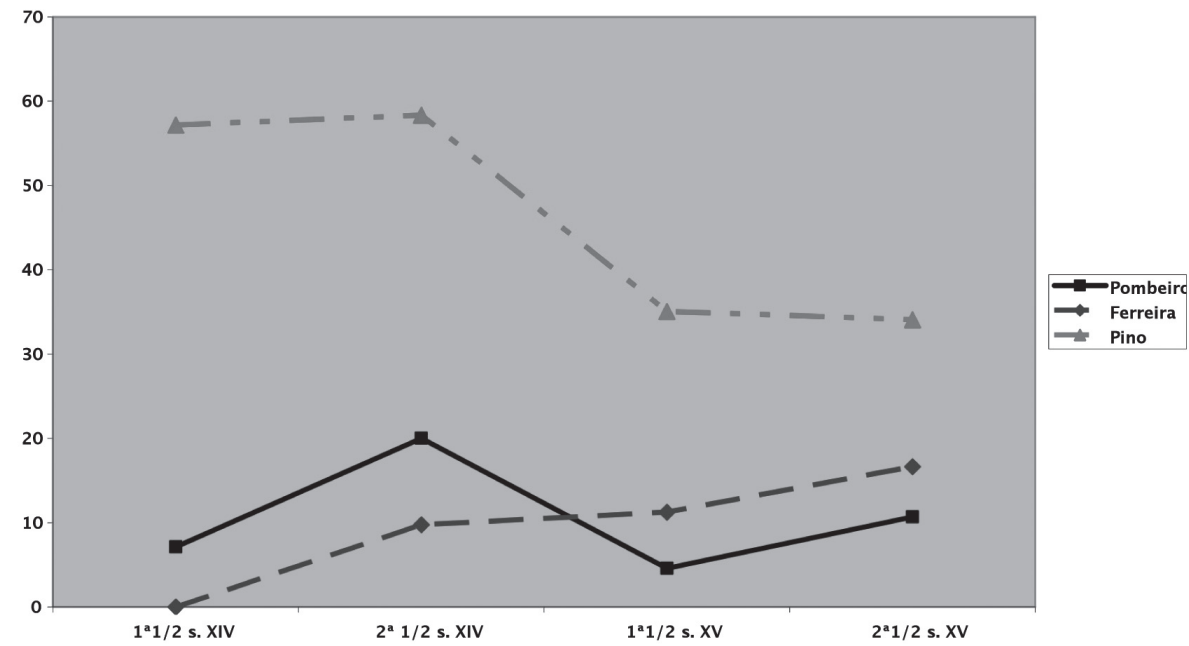

Es común observar en diferentes latitudes de la geografía gallega, otra tipología de bienes susceptible de ser satisfecha mediante renta en dinero. Son aquellas propiedades cultivadas indirectamente mediante la fórmula del subforo, por la cual, el forero cede a terceras personas el dominio útil de una explotación que previamente ha recibido del forista o propietario real $^{28}$. Su repercusión, en relación con la recaudación de las rentas, estriba en que tal contrato, permite la creación de un intermediario entre el señor y el usufructuario con la facultad de asegurar a dicho señor, una vez detraída la parte correspondiente por el subforo, la recepción de la totalidad de las rentas ${ }^{29}$. Sin embargo, de los veinticuatro subforos documentados en el área de dominio de estos

\footnotetext{
${ }^{26}$ Julio VALDEÓn BARUQUE, Los Trastámaras. El triunfo de una dinastía bastarda, Madrid, 2001, p. 20.

${ }^{27}$ Charles-E. DufourcQ y Jean GAUTIER-DALCHÉ, Historia económica y social de la España cristiana en la Edad Media, Barcelona, 1983, p. 253.

${ }^{28}$ Francisco Javier PÉREZ RodrígueZ, O mosteiro de Melón no século XV, Ourense, 1996, p. 48.

${ }^{29}$ Dolores MARIÑo VeIRAS, Señorío de Santa María de Meira (De 1150 a 1525). Espacio rural, régimen de propiedad y régimen de explotación en la Galicia medieval, La Coruña, 1983, pp. 194195.
} 
tres monasterios localizados en el valle de Lemos, solamente en dos ocasiones se establece el dinero como renta principal de tales contratos, siendo más usual, con trece menciones la exigencia de renta fija en especie. Otra peculiaridad, en relación con las exacciones monetarias de esta área, es la referente a la duración de la cesión del dominio útil de los bienes aforados. Era costumbre generalizada en la Galicia medieval hasta mediados del siglo XIV, estipular de corta duración o vitalicio aquellos foros cuyas rentas se hubiesen de satisfacer en numerario ${ }^{30}$. En el ámbito de este estudio, en cambio, esta predisposición se haya lejos de cumplirse. De las cuatro referencias a renta en dinero relativas a la documentación de San Vicente del Pino entre 1316 y 1336, en todas ellas la duración del contrato se establece a tres voces (en tres ocasiones corresponden a un forero y dos voces, en una a un matrimonio y una voz). En la misma sintonía, la perdurabilidad del único foro perteneciente a este periodo (1325), en el que el monasterio de San Vicente de Pombeiro exige renta en dinero, lejos de ser vitalicio, se establece en un forero y sus hijos e hijas. Aceptando una media aproximada de veintinueve años por $\mathrm{voz}^{31}$, se deduce una duración de estos contratos forales entre sesenta y noventa años. A partir de la segunda mitad del siglo XIV, esta tendencia temporal, sobre todo en lo que se refiere a San Vicente de Pombeiro, no solo se mantiene sino que se incrementa. De esta manera, la duración de los foros satisfechos a través de renta monetaria emitidos por este monasterio, en cuatro de las cinco menciones para un periodo comprendido entre 1396 y 1398, se estipula en cuatro voces (en tres ocasiones afectan a un forero y tres voces, en una a un matrimonio y dos voces). Esta articulación enfitéutica, si bien beneficiaba al emisor de la renta, en cuanto que las detracciones no podían ser modificadas durante un largo periodo de tiempo, no haría más que agravar la situación económica de aquellos señoríos monásticos sustentadores de este tipo de censos, al perder éstos gran parte de su valor, en el momento en que la moneda es víctima, ya desde la época de Alfonso X y a lo largo de la primera mitad del siglo XIV, de las continuas devaluaciones monetarias que se creen necesarias para hacer frente a este periodo inflacionista ${ }^{32}$.

Es durante esta época de crisis, y con la finalidad de fijar al campesinado en las explotaciones agrarias, compensando así las terribles pérdidas demográficas, cuando el modelo de contrato agrario enfitéutico a largo plazo y de rentas no muy cuantiosas, se convierte en el más difundido en esta época, no solamente en Galicia, sino en toda la meseta norte castellana ${ }^{33}$. Para estudiar este fenómeno, los datos más fidedignos son los que proceden del análisis de la evolución de la cuantía proporcional de la cosecha reclamada por los distintos señoríos. En lo que respecta a la Galicia meridional, se puede apreciar una tendencia generalizada, por parte de la autoridad eclesiástica, de exigir durante la segunda mitad del siglo XIV, unas exacciones onerosas (sobre la mitad o el tercio de la cosecha) que se van moderando paulatinamente a medida que nos adentramos en la centuria posterior ${ }^{34}$. Esta tendencia, se confirma respecto a las detracciones exigidas por el monasterio de Santa María de Ferreira. Aquí, durante la segunda mitad del siglo XIV, la exigencia del tercio del cereal producido alcanza nada menos que el $50 \%$ de todas las menciones relativas a la renta proporcional, sigue a este porcentaje, un $23,07 \%$ y un $19,23 \%$ relacionados respectivamente con la mitad y el tercio del vino producido. En la primera mitad de la centuria siguiente, estas exigencias se suavizan,

\footnotetext{
${ }^{30} \mathrm{M}^{\mathrm{a}}$.L. Ríos, As orixes do foro, pp. 103-105.

${ }^{31} \mathrm{M}^{\mathrm{a}}$.C. SÁNCHEZ, El Bajo Miño, p. 140.

${ }^{32}$ Paulino Iradiel et al., Historia medieval de la España cristiana, Madrid, 1995, p. 481.

${ }_{33}$ Enric GuINot RodríGueZ, La Baja Edad Media en los siglos XIV- XV. Economía y sociedad, Madrid, p. 184.

${ }^{34}$ E. ÁlVAREZ, Las exigencias señoriales, pp. 117-152/131 y 135.
} 
siendo predominantes en un 70,44\% las proporciones del cuarto tanto del grano como del vino cultivado.

\section{CANTIDAD DE RENTA PROPORCIONAL DEMANDADA EN SANTA MARÍA DE FERREIRA}

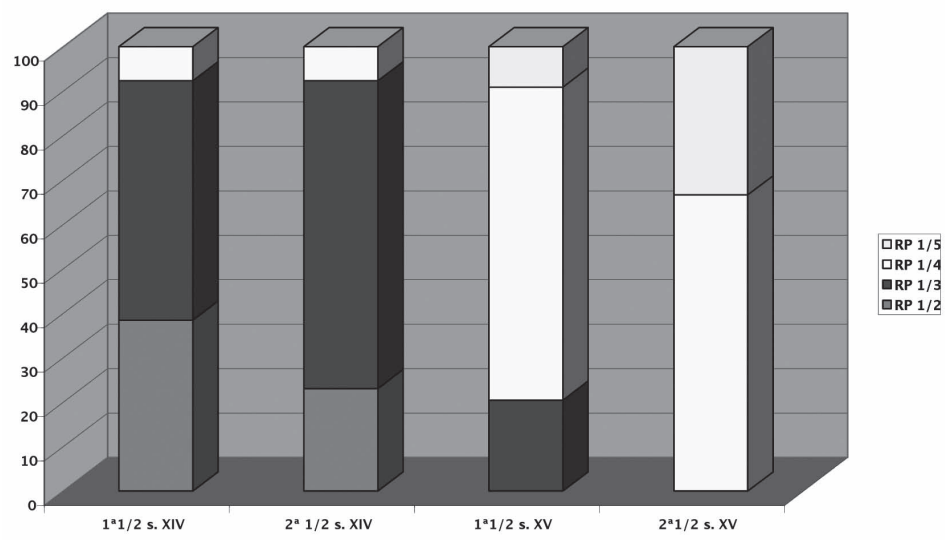

En lo relativo al monasterio de Pombeiro, no se aprecian grandes modificaciones en cuanto a la proporción exigida a lo largo de la segunda mitad del siglo $\mathrm{XIV}$, y la primera del siglo posterior, siendo mayoritarias las rentas exigidas sobre el tercio y cuarto de la cosecha. Será a partir de la segunda mitad del siglo XV, cuando las exacciones sobre el tercio dejen de tener relevancia dejando la preeminencia, con un porcentaje del $64,87 \%$ sobre el resto, al cuarto y quinto de lo producido.

\section{CANTIDAD DE RENTA PROPORCIONAL DEMANDADA EN SAN VICENTE DE POMBEIRO}

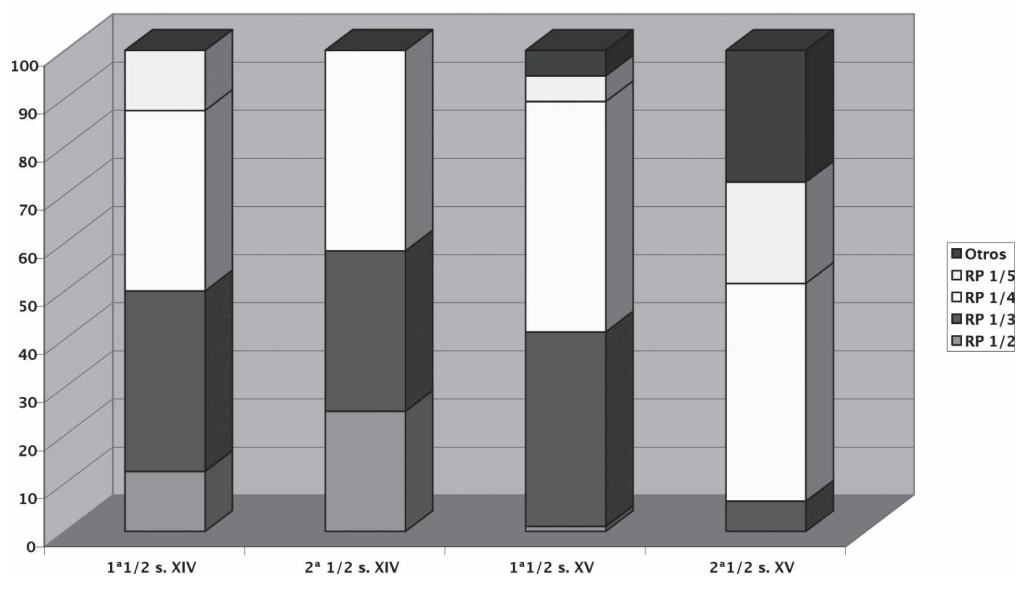


Por último, respecto al monasterio de San Vicente del Pino, si bien los exiguos datos que atañen a la renta proporcional para la segunda mitad del siglo XIV, no permiten ningún tipo de valoración, parece evidente que a medida que avanza el siglo $\mathrm{XV}$ en sus primeros diez lustros, los rectores monásticos se acogen a la tónica generalizada de exigir rentas moderadas sobre el cuarto $(56,75 \%)$, y el quinto $(32,42 \%)$ de la producción. Constante que se prolonga, a lo largo de la segunda mitad de este periodo, en el que la demanda del quinto de la cosecha se sitúa en una cifra del 51,85\% en relación con el resto de rentas proporcionales.

\section{CANTIDAD DE RENTA PROPORCIONAL DEMANDADA EN SAN VICENTE DEL PINO}

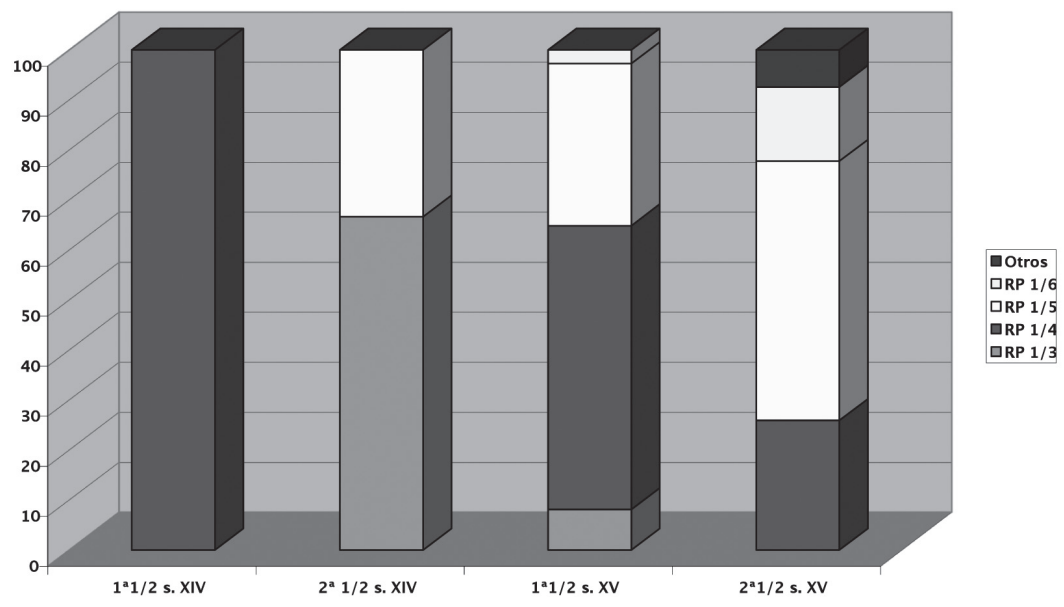

Rentas de Santa María de Ferreira

\begin{tabular}{|l|c|c|c|c|}
\hline & $\mathbf{1}^{\mathbf{a}} \mathbf{1 / 2}$ s. XIV & $\mathbf{2}^{\text {a }} \mathbf{1 / 2}$ s. XIV & $\mathbf{1}^{\mathbf{a}} \mathbf{1} \mathbf{2}$ s. XV & $\mathbf{2}^{\mathbf{a}} \mathbf{1} \mathbf{2} \mathbf{~ s . ~ X V}$ \\
\hline RD & & $4-9,75 \%$ & $9-11,25 \%$ & $5-16,62 \%$ \\
\hline REFC & $2-7,14 \%$ & $5-12,19 \%$ & $10-12,5 \%$ & $10-31,25 \%$ \\
\hline REPC 1/2 & $2-7,14 \%$ & & & \\
\hline REPC 1/3 & $10-35,71 \%$ & $13-31,71 \%$ & $2-2,5 \%$ & \\
\hline REPC 1/4 & $2-7,14 \%$ & $1-2,43 \%$ & $13-16,25 \%$ & $2-6,25 \%$ \\
\hline REFV & & $4-9,75 \%$ & $14-17,5 \%$ & $9-28,12 \%$ \\
\hline REPV 1/2 & $8-28,57 \%$ & $6-14,63 \%$ & & \\
\hline REPV 1/3 & $4-14,28 \%$ & $5-12,19 \%$ & $7-8,75 \%$ & \\
\hline REPV 1/4 & & $1-2,43 \%$ & $18-22,5 \%$ & $2-6,25 \%$ \\
\hline REPV 1/5 & & & $4-5 \%$ & $2-6,25 \%$ \\
\hline RE+D & & $2-4,87 \%$ & $3-3,75 \%$ & $2-6,25 \%$ \\
\hline
\end{tabular}




\section{Rentas de San Vicente de Pombeiro}

\begin{tabular}{|c|c|c|c|c|}
\hline & $1^{\mathrm{a}} 1 / 2$ s. XIV & $2^{\mathrm{a}} 1 / 2$ s. XIV & $1^{\mathrm{a}} 1 / 2 \mathrm{~s} . \mathrm{XV}$ & $2^{\mathrm{a}} 1 / 2$ s. XIV \\
\hline RD & $1-7,14 \%$ & $5-20 \%$ & $5-4,58 \%$ & $14-10,68 \%$ \\
\hline REFC & $3-21,42 \%$ & $5-20 \%$ & $5-4,58 \%$ & $10-7,63 \%$ \\
\hline REPC 1/2 & $1-7,14 \%$ & & & \\
\hline REPC 1/3 & $1-7,14 \%$ & & $2-1,83 \%$ & $1-0,76 \%$ \\
\hline REPC 1/4 & $1-7,14 \%$ & & $9-8,25 \%$ & $8-6,10 \%$ \\
\hline REPC 1/5 & $1-7,14 \%$ & & & $4-3,05 \%$ \\
\hline REPC 1/6 & & & & $1-0,76 \%$ \\
\hline REPC 1/8 & & & & $1-0,76 \%$ \\
\hline REFV & $2-14,28 \%$ & $1-4 \%$ & $4-3,66 \%$ & $9-6,87 \%$ \\
\hline REPV 1/2 & & $2-8 \%$ & $1-0,91 \%$ & \\
\hline REPV 1/3 & $1-7,14 \%$ & $1-4 \%$ & $18-16,51 \%$ & $2-1,52 \%$ \\
\hline REPV 1/4 & $2-14,28 \%$ & $3-12 \%$ & $20-18,34 \%$ & $17-12,97 \%$ \\
\hline REPV 1/5 & & & $3-2,75 \%$ & $11-8,39 \%$ \\
\hline REPV 1/6 & & & $1-0,91 \%$ & $3-2,29 \%$ \\
\hline REPV 1/7 & & & $1-0,91 \%$ & $3-2,29 \%$ \\
\hline REPV 2/7 & & & & $1-0,76 \%$ \\
\hline REPV 1/8 & & & $1-0,91 \%$ & $10-7,63 \%$ \\
\hline REPV 1/9 & & & $2-1,83 \%$ & $7-5,34 \%$ \\
\hline REFCS & & $2-8 \%$ & $1-0,91 \%$ & $3-2,29 \%$ \\
\hline REPCS $1 / 2$ & & $1-4 \%$ & & \\
\hline REPCS 1/3 & $1-7,14 \%$ & $3-12 \%$ & $18-16,51 \%$ & $3-2,29 \%$ \\
\hline REPCS 1/4 & & $2-8 \%$ & $16-14,67 \%$ & $18-13,74 \%$ \\
\hline REPCS 1/5 & & & $2-1,83 \%$ & $5-3,81 \%$ \\
\hline RE+D & & & & \\
\hline
\end{tabular}

Rentas de San Vicente del Pino

\begin{tabular}{|l|c|c|c|c|}
\hline & $\mathbf{1}^{\mathbf{a}} \mathbf{1 / 2} \mathbf{~ s . ~ X I V}$ & $\mathbf{2}^{\mathbf{a}} \mathbf{1} / \mathbf{2} \mathbf{~ s . ~ X I V}$ & $\mathbf{1}^{\mathbf{a}} \mathbf{1} \mathbf{2} \mathbf{~ s . ~ X V}$ & $\mathbf{2}^{\mathbf{a}} \mathbf{1 / 2} \mathbf{~ s . ~ X V}$ \\
\hline RD & $4-57,14 \%$ & $7-58,33 \%$ & $55-35,03 \%$ & $61-34,07 \%$ \\
\hline REFC & $1-14,28 \%$ & $1-8,33 \%$ & $36-22,92 \%$ & $53-29,60 \%$ \\
\hline REPC 1/3 & & $1-8,33 \%$ & $1-0,63 \%$ & \\
\hline REPC 1/4 & $1-14,28 \%$ & & $8-5,09 \%$ & $6-3,35 \%$ \\
\hline REPC 1/5 & & & $3-1,91 \%$ & $3-1,67 \%$ \\
\hline REFV & & $1-8,33 \%$ & $19-12,10 \%$ & $30-16,75 \%$ \\
\hline REPV 1/3 & & $1-8,33 \%$ & $2-1,27 \%$ & \\
\hline REPV 1/4 & $1-14,28 \%$ & & $13-8,28 \%$ & $1-0,55 \%$ \\
\hline REPV 1/5 & & $1-8,33 \%$ & $9-5,73 \%$ & $11-6,14 \%$ \\
\hline
\end{tabular}




\begin{tabular}{|l|l|l|l|l|}
\hline REPV 2/5 & & & & $1-0,55 \%$ \\
\hline REPV 1/6 & & & $1-0,63 \%$ & $4-2,23 \%$ \\
\hline REPV 1/9 & & & & $1-0,55 \%$ \\
\hline RE+D & & & $10-6,36 \%$ & $8-4,46 \%$ \\
\hline
\end{tabular}

$\mathrm{RD}=$ Renta en dinero; REFC $=$ Renta en especie fija de cereal; REPC $=$ Renta en especie proporcional de la producción de cereal; REFV = Renta en especie fija de vino; REPV = Renta en especie proporcional de la producción de vino; REFCS = Renta en especie fija de castañas; REPCS $=$ Renta en especie proporcional de la producción de castañas; RE+D = Renta mixta en dinero y especie.

\section{RENTA DERIVADA DEL RECONOCIMIENTO DEL SEÑORÍO}

Son las prestaciones en trabajo, las exigencias que más netamente se derivan de la expresión de señorío que el gran propietario ejerce sobre el conjunto de campesinos que integra su dominio. De entre ellas cobran una mayor relevancia las sernas, herencia del sistema señorial romano, que en virtud del reconocimiento de señorío sobre las tierras que usufructuaban, se manifiestan como la imposición hacia los vasallos de una serie de faenas agrícolas durante un espacio de tiempo determinado en la reserva señorial ${ }^{35}$. Gran parte de estas prestaciones laborales, estaban estrechamente vinculadas a actividades de carácter agrícola relativas al cultivo de cereales (arar, sembrar, segar), viñedos (podar, vendimiar), monte (recolección de frutos y leña), y transporte de los frutos de las cosechas ${ }^{36}$. Otras, en cambio, se alejaban de esta naturaleza estrictamente agraria centrándose en la obligación, exigida al campesino en razón del señorío que sobre él era ejercido, relativa a la construcción de cercas o caminos, reparación de puentes o servicios de mandadería ${ }^{37}$. La pervivencia de este tipo de exigencia conlleva una cronología que abarca desde el siglo $\mathrm{X}$, en el que aparecen las primeras, hasta la segunda mitad del siglo XIII, momento en el que las menciones comienzan a descender en cuanto presencia documental se refiere, gracias a un proceso de conmutación de las prestaciones en trabajo por censos en dinero o especie ${ }^{38}$. Esta tendencia, común en toda Europa, viene originada por la gran demanda de numerario requerida por los diferentes señores, ante la perspectiva de una sociedad cada vez más mercantilista, y en consecuencia, más acorde con la necesidad de una reducción de la explotación directa a favor de la indirecta ${ }^{39}$. El exiguo número de referencias correspondientes a este tipo de prestaciones, es un hecho que ya se parece evidenciar en Galicia entre mediados del siglo XII y el XIII ${ }^{40}$. En la documentación objeto

${ }^{35}$ Enrique RODRÍGUEZ-PICAVEA, La formación del feudalismo en la meseta meridional castellana: los señoríos de la Orden de Calatrava en los siglos XII-XIII, Madrid, 1994, p. 346.

${ }^{36}$ María Isabel ALFONSO DE SALDAÑA, La contestación campesina a las exigencias de trabajo señoriales en Castilla y León. Las formas y su significación simbólica en Habitar, producir, pensar el espacio rural. De la Antigüedad al Mundo Moderno, (Paola MiCELI, y Julián GALleGo, eds.), Buenos Aires, 2008, pp. 257-289/261-262.

${ }^{37}$ Carlos de Ayala MARTínez et al., Economía y sociedad en la España medieval, Madrid, 2004, p. 73.

38 Julián Clemente RAmos, Las sernas en el Becerro de las Behetrías, "Homenaje al profesor Juan Torres Fontes", 1, (1987), pp. 299-318/310-312.

${ }^{39}$ Maurice DoBB, Estudios sobre el desarrollo del capitalismo, México D.F., 2005, pp. 49-106.

${ }^{40} \mathrm{M}^{\mathrm{a}}$.L. Ríos, As orixes do foro, pp.128-135. 
de este estudio, la serna especificada como tal, presenta un escaso protagonismo, ya que solamente aparece mencionada en dos ocasiones, ambas en la primera mitad del siglo $\mathrm{XIV}^{41}$. La obligación de que uenades a seara o de lavrar na searra, confirma la polisemia del término, que incide tanto en la denominación de la tierra señorial o reserva, como en la prestación consistente en labrar ${ }^{42}$. En cuanto a la duración de la misma, varía de la vez por semana requerida por el monasterio de Pombeiro, al día mensual solicitado por el de Santa María de Ferreira. Este último supuesto, coincide con la pauta generalizada en el resto de la corona de Castilla, de limitar esta exigencia en el peor de los casos a una vez al mes ${ }^{43}$. Sin embargo, la serna semanal relativa a la colección diplomática de Pombeiro, se encuentra en este periodo mucho menos documentada, siendo más frecuente encontrársela en la época altomedieval, y orientada sobre una población claramente servil ${ }^{44}$. Es por ello lógico pensar, que la pervivencia de este modelo de renta, venga explicada por un aumento de la demanda de mano de obra en periodos temporales muy puntuales del año. Concretamente en este foro, se menciona la semana de San Sebastián en Enero, tiempo proclive a ciertas tareas agrícolas como la poda de las viñas, o la siembra de variedades de cereal de ciclo intermedio o precoz. La escasez de referencias, respecto a este tipo de prestaciones laborales, se puede entender a causa de la pérdida del peso específico que sufre en esta época la reserva frente la gestión indirecta del patrimonio monástico, pero tampoco se puede desdeñar la idea que apunta a que estas prácticas fuesen tan comúnmente aceptadas y sobreentendidas por el campesino en su condición de vasallo, que no tuvieran necesidad de una expresión escrita ${ }^{45}$.

Una mayor presencia documental adquiere el término servicio, que para Alfonso de Saldaña en el ámbito de las tierras castellanoleonesas no es sino sinónimo de serna ${ }^{46}$. Esta afirmación se constata en la documentación de San Vicente del Pino, donde estos servicios quedan referidos en veintinueve ocasiones, siendo los más comunes los servicios de era (diez menciones), los de malla (seis menciones) y los de lagar (dos menciones), obligaciones todas ellas, íntimamente ligadas al final del proceso de producción agrícola. Es en 1453, cuando comienza una propensión a la conmutación de estas prestaciones por una renta en especie ${ }^{47}$, tendencia que se hace predominante a partir de $1461^{48}$. Dos exigencias, también incluidas en la colección diplomática de este monasterio, se hallan estrechamente vinculadas al concepto de serna, en la primera el forero ha de satisfacer un seruiço con o corpo un día cada

${ }^{41}$ ACO, Monástica, Pombeiro, núm. 2022. Ed. M. LuCAS y P. LuCAS, El priorato benedictino, pp. 87-88. AFP., 1/38. Ed. José Ignacio FERNÁNDEZ DE VIANA Y VIEITES, Colección diplomática del monasterio de Santa María de Ferreira de Pantón, Lugo, 1994, pp. 60-61.

${ }^{42}$ Santiago JimÉnEz GómEZ, Análisis de la terminología agraria en la documentación lucense del siglo XIII en Actas de las I Jornadas de Metodología Aplicada de las Ciencias Históricas, v.2, Santiago de Compostela, 1975, pp. 115-133/123.

${ }^{43}$ Julián Clemente Ramos, La economía campesina en la corona de Castilla (1000-1300), Barcelona, 2004, p. 188.

${ }^{44} \mathrm{M}^{\mathrm{a}}$. I. ALFONSO dE SALDAÑA, La contestación campesina, pp. 257-289/261

${ }^{45}$ Esperanza Botella PomBo, La Serna: Ocupación, organización y explotación del espacio en la Edad Media (800-1250), Santander, 1988, p. 62.

${ }^{46}$ María Isabel AlfONSO DE SALDAÑA, Las sernas en León y Castilla. Contribución al estudio de las relaciones socio-económicas en el marco del señorío medieval, "Moneda y crédito", 129 (1974), pp. 153-210/166-168.

${ }^{47}$ AHN, Sección clero, Carpeta $1205, \mathrm{n}^{\circ} 1$.

${ }^{48}$ AHN, Sección clero, Carpeta 1206, $n^{\circ} 7, n^{\circ} 11$; Carpeta 1207, $n^{\circ} 3, n^{\circ} 6, n^{\circ} 9, n^{\circ} 14, n^{\circ} 22$; Carpeta $1209, \mathrm{n}^{\circ} 4$. 
año ${ }^{49}$, en la segunda se le emplaza a que ajudedes a labrar a o prior ${ }^{50}$. Otra categoría en el seno semántico del término servicio, es la que hace referencia a la observancia por parte del vasallo de facilitar a su señor alimento y albergue, cada vez que le fuera a visitar ${ }^{51}$. Esta acepción, sería tan común en la documentación gallega medieval, que Villa-amil y Castro en su estudio sobre los foros de Galicia, llegó a otorgar al servicio y al yantar el mismo significado ${ }^{52}$. Por último, no es inusual la presencia de la fórmula et daredes de o por seruiço, excluyéndose cualquier tipo de especificación relacionada con la naturaleza de dicha prestación. Esta modalidad, aparece en la colección diplomática de San Vicente del Pino en siete ocasiones, y en la de Pombeiro en otras dos, prevaleciendo la renta en especie (cinco menciones), sobre las estipuladas en dinero (dos menciones), y sobre aquéllas tres en las que no se concreta el carácter de tal detracción. Bien es posible que estos servicios, no fuesen más que la conmutación en especie y dinero de una antigua prestación laboral, pero también es probable que su significación pueda tener origen en el reconocimiento de señorío del que ha de ser partícipe el forero, a través de una visita anual a los rectores monásticos, siempre acompañada de una serie de viandas entre las que no podía faltar el pan, la carne y el vino ${ }^{53}$. El obsequio, por parte del vasallo a su señor, de un cerdo con su pan y vino el día de San Andrés, constituía la forma corriente de satisfacer este derecho, que hundía sus raíces en la Alta Edad Media, periodo en el que los términos obsequium y servitium eran usados para denominar las obligaciones del encomendado $^{54}$ La escasez de referencias nominales a este tipo de derecho señorial en los contratos forales del monasterio de San Vicente de Pombeiro, se explica por la dispensabilidad del requisito relativo a la formulación escrita de dicho término en cuestión ; en cinco ocasiones, la renta y plazo de entrega típicas de tal detracción se establecen según el uso y costumbre de la tierra, del coto, o del monasterio sin que el cenobio considere necesario, por sobreentendido, que el vocablo servicio quede reflejado en el documento ${ }^{55}$. Estrechamente vinculada con esta detracción, se sitúa la obligación del forero de honrar la fiesta patronal de los distintos monasterios con una boa vianda o con daquello que teverdes. Esta costumbre, tuvo un arraigo especial en el dominio del monasterio de San Vicente de Pombeiro, siendo su presencia algo más moderada en el de San Vicente del Pino, mientras que en el ámbito de Santa María de Ferreira, su protagonismo fue mucho menor, y solamente circunscrito a la segunda mitad del siglo XV. Este acto de romería comportaría una significación implícita de sometimiento, fidelidad y respeto hacia el prior y el convento ${ }^{56}$. De carácter más circunstancial y extraordinario que el servicio y el yantar, se encuentra la colleita, prestación consistente en la reclamación, a discreción de los rectores monásticos, de carne, pan y vino una vez al año. Esta prestación es ocasional, tal como se refleja en

${ }^{49}$ AHN, Sección clero, Carpeta $1201, \mathrm{n}^{\circ} 5$.

${ }^{50}$ AHN, Sección clero, Carpeta 1206, nº 16.

51 “...et paredes mays cada hun anno a os priores que foren do dito mosteyro, un seruiço, que seja sen maliçia, por dia de San Pedro do mes de juyo...” (AHN, Sección clero, Carpeta 1204, n 3).

52 J. Villa-AMIL, Los foros de Galicia, pp. 95-96.

${ }^{53}$ Manuel LuCAS Álvarez y Pedro LuCAS DomíngueZ, El monasterio de San Clodio do Ribeiro en la Edad Media: estudio y documentos, A Coruña, 1996, p. 181.

${ }^{54}$ Abilio BARBero y Marcelo VigIL, La formación del feudalismo en la Península Ibérica, Barcelona, 1991, p. 170.

${ }^{55}$ ACO, Monástica, Pombeiro, núm. 3750 y 3751, 4100, 4461, 4647, 4961. Ed. M. LUCAS y P. LuCAS, El priorato benedictino de, pp. 174-175, 228-229, 260-261, 291-292, 314-315.

${ }^{56}$ M. LUCAS y P. LUCAS, El priorato benedictino de, p. 45. 
el único documento en el que aparece especificada ${ }^{57}$, siendo solamente susceptible de ser satisfecha cuando fuese demandada por arbitrio monástico, y nunca en caso contrario, circunstancia que no hacía de ella una detracción fija de carácter anual como sucedía con el yantar.

El yantar, así como la posada, son prestaciones que a partir del siglo XI, y al igual que sucedería con los atributos de justicia propios de la monarquía, son adquiridos por los distintos poderes señoriales, de acorde con el proceso de formación del señorío banal o jurisdiccional ${ }^{58}$. Partiendo de esta coyuntura, los señoríos monásticos se convertirían en sujetos activos en la recepción de dichas exigencias, primero en el marco jurisdiccional de los cotos, a raíz de los privilegios concedidos por los distintos monarcas, para más adelante extender, utilizando los contratos forales como mecanismos vehiculares, dichas prerrogativas señoriales a todos sus vasallos. ${ }^{59}$ En Castilla y León, el deber de alojamiento del rey o señor, a diferencia de siglos precedentes, acabaría por tener un carácter generalizado a partir del siglo XIII, siendo mucho más común en León que en Castilla. En relación con otras prestaciones como el conducho, la posada o el hospedaje, es el yantar el que con más frecuencia es requerido ${ }^{60}$. En consecuencia, las instituciones señoriales además de ser receptoras del yantar, también se constituirían en sujetos pasivos, al estar obligadas a satisfacer dicho tributo al soberano. No obstante, el monarca en ocasiones, eximía a los monasterios del pago del yantar, situación que se dio en 1259 cuando Alfonso X exonera al cercano monasterio de San Salvador de Chantada tanto del yantar como del pedido ${ }^{61}$. Esta liberación de derechos reales, podría albergar únicamente una naturaleza parcial, como se desprende en 1277 , cuando este mismo monarca, correspondiendo a la petición de los abades de los monasterios cistercienses de Galicia, ordena a su merino mayor que no les exija el pago del yantar, pero que mantenga la vianda, y que les cobre el conducho en caso de una visita real por los dominios de dichos monasterios ${ }^{62}$. El conducho y el yantar pueden parecer figuras semejantes, sin embargo, mientras el primer término es empleado en relación al servicio de alimentos, el segundo va estrechamente vinculado a una obligación pecuniaria ${ }^{63}$. De este modo, el conducho no se redime ni se sustituye por un censo en metálico, y lo que es más relevante, el señor no solo albergaba el derecho de reclamar el conducho, sino que tenía además la obligación de consumirlo in situ ${ }^{64}$. En lo relativo a la documentación monástica del ámbito de este estudio, aunque el conducho como expresión vinculante se encuentra ausente de los contratos forales, la obligación del forero, no dejaría de encaminarse hacia el deber de dar de comer y beber sin malicia, al mayordomo o a cualquier enviado

\footnotetext{
57 "Et que me diades de cada hun anno huna colleyta de pan et de carne et de vinno, a min et a dous ommes et a hun moço et huna besta seendo uos demandado en no dito anno. Et non uos seendo demandado que non sejades a elo tiudo" AHN, Sección clero, Carpeta 1198, nº 9.

${ }^{58}$ Georges DuBy, Guerreros y campesinos. Desarrollo inicial de la economía europea (5001200), Madrid, 1999, p. 288.

${ }^{59}$ Eleutino ÁlvareZ ÁlvareZ, El yantar y el hospedaje foral en el sur de Galicia (1340-1450), "Boletín Auriense", 13 (1983), pp. 137-144/138

${ }^{60}$ Miguel Ángel LADERO QUESADA, El sistema impositivo en Castilla y León. Siglos X-XIII en I jornadas sobre documentación jurídico-administrativa, económico-financiera y judicial del Reino Castellano leonés, (Ángel RIESCO TERRERO, coord.), Madrid, 2002, pp. 283-302/291.

${ }^{61}$ AHN, Sección clero, Carpeta 1067, nº 12.

${ }^{62}$ Luis SÁNCHEZ BeldA, Documentos reales de la Edad Media referentes a Galicia, Madrid, 1953, p. 349, documento $\mathrm{n}^{\text {o }} 804$.

${ }^{63}$ Nilda Guglielmi, Posada y yantar. Contribución al estudio del léxico de las instituciones medievales, "Hispania", 102 (1966), pp. 165-219/191.

${ }^{64}$ María Isabel LoRING GARCÍA y Abilio BARBERo DE AGUILERA, "Del palacio a la cocina": estudio sobre el conducho en el fuero viejo, "En la España medieval", 14, (1991), pp. 19-44/28.
} 
del monasterio, que acudiese a partir y medir la cosecha, y recaudar la correspondiente renta. A diferencia de lo que sucedía en las áreas de dominio de la mayoría de los monasterios del sur de Galicia, donde fue habitual la identificación de la palabra yantar con una renta en dinero ${ }^{65}$, en la Tierra de Lemos, en cambio, dicho vocablo solamente aparece en una ocasión, y relacionado con el pago a la abadesa de Santa María de Ferreira de pan et de viño et de carnes $^{66}$. En consecuencia, es plausible colegir que la conmutación de esta exigencia por una renta en numerario, al menos en lo que a esta comarca se refiere, estuvo lejos de producirse. Junto al yantar, otra prestación típicamente jurisdiccional, es la referida a la obligación del vasallo de hospedar y dar albergue al señor. Esta prerrogativa, sólo acontece en dos ocasiones dentro de las colecciones diplomáticas de los tres monasterios estudiados, en la primera, el forero ha de agasajar al prior o al monje cuando por éstos for neçesario de pousar en no dito lugar ${ }^{67}$, en la segunda, la abadesa tiene derecho de recibir lume e agoa e sal e quama sen pecunia lebar, cuando se hospede en la casa que ha cedido mediante foro en Monforte ${ }^{68}$; exigencia que comparte el obispado de Lugo en provecho de sus beneficiarios, en compensación por la cesión del dominio útil de viviendas situadas en esta misma villa ${ }^{69}$. Es cierto que la satisfacción de este tipo de prestaciones, no solamente alteraba la vida cotidiana del campesinado, sino que también mermaba sus ya de por si escasos excedentes. Sin embargo, la finalidad última perseguida por las instituciones señoriales no era tanto económica como social, lo que realmente se buscaba con estas exigencias, era el reconocimiento del señorío por parte del vasallo ${ }^{70}$. La similitud de estas cargas con las prestaciones en trabajo, estribaba en que ambas entrañaban una manifestación pública y externa del domino señorial, y de la dependencia campesina, siendo a su vez generadoras de un fuerte impacto psicológico en el seno del campesinado ${ }^{71}$.

Relacionadas con las prestaciones laborales, pero de distinta naturaleza, son aquéllas condiciones de obligado cumplimiento para hacer efectivo el foro, orientadas a la mejora del bien aforado durante el tiempo de disfrute de dicho bien. En este punto cada monasterio expone sus preferencias, no obstante la documentación refleja una serie de tareas recurrentes demandadas por todos los cenobios, encaminadas a incrementar la productividad de la explotación cedida. La más común, fue la relativa a cultivar vid a expensas del monte yermo, o para maximizar el rendimiento de un terreno ya en explotación, articulándose una política de nuevas roturaciones, recurrente en la mentalidad de los rectores monásticos desde la primera mitad del siglo XV en adelante, con el fin de paliar de alguna forma los efectos de la crisis de la segunda mitad de la centuria anterior, adaptando la producción, tanto a la demanda de los mercados urba-

${ }^{65}$ E. ÁlvareZ, El yantar y el, pp. 137-144/142.

${ }^{66}$ AFP., 2/136. Ed. J. I. FERNÁNDEZ DE VIANA, Colección diplomática del, pp. 174-175.

${ }^{67}$ ACO, Monástica, Pombeiro, núm. 4220. Ed. M. LuCAS y P. LUCAS, El priorato benedictino de, pp. 236-237.

${ }^{68}$ AFP., 3/205. Ed. J. I. FERnÁNDEZ DE VIANA, Colección diplomática del, pp. 273-274.

69 “....et que quando se aconteçer de yr et estar en a dita villa de Monforte algun beneficiado desta iglesia que lle dedes pousada et cama en a dita casa et agoa et fogo et sal..." AHN, Códice 419 B, f. 22r. Ed. María Xosé PorTela Silva, Documentos da catedral de Lugo. Século XV, Santiago de Compostela, 1998, pp. 298-299.

${ }^{70}$ Francisco Javier FERNÁNDEZ CONDE, El señorío del cabildo ovetense: estructuras agrarias de Asturias en el tardo medievo, Oviedo, 1994, p. 154.

${ }^{71}$ Julián CLEMENTE RAMOS, Supuestos teóricos para el análisis de las estructuras señoriales en Señorío y feudalismo en la Península Ibérica, (E. SARASA y E. SERRANO, Eds.), v. 3, pp. 57-68/63. 
nos como a la evolución de precios agrarios del momento ${ }^{72}$. La política más usual de los diferentes monasterios sería la encaminada, dado que estas condiciones repercuten en provecho del propietario eminente, a suavizar el rigor de las detracciones del fruto de estas nuevas roturaciones, y en menor medida, a eximir del pago de las mismas durante el periodo de tiempo estipulado de carencia, hasta que la productividad plena fuese una realidad. Un condicionante más para hacer efectivo el contrato de foro, sería el referente a la acción de plantar árboles, y más concretamente castaños, requisito usual, tanto en la documentación de San Vicente del Pino como en la de San Vicente de Pombeiro. En lo que respecta a este último monasterio, famoso por la importancia de la castaña como renta-producto dentro de su patrimonio, las obligaciones del forero van más allá del mero plantío, y se dirigen hacia ciertas actividades, como la poda y el injerto, necesarias para que estas especies arbóreas alcanzasen los niveles exigidos de productividad ${ }^{73}$. Por último, hay que señalar una última cláusula, no carente de cierta asiduidad en los contratos forales, y de cumplida observancia por parte del forero, correspondiente a aquellas labores encaminadas a garantizar el buen estado de conservación, e incluso si fuese menester la construcción, tanto de las viviendas campesinas como de sus anexos, mayoritariamente bodegas, lagares y cortes ${ }^{74}$. Tampoco hay que olvidar, que de entre las prestaciones a las que el forero se halla sujeto en virtud de su dependencia personal, se encuentra la especificada como transporte de la renta-producto a los centros establecidos para la recaudación de la misma. Si bien, en la mayoría de las ocasiones está condición queda formalizada, en otras, sería el agente señorial el encargado de realizar dicha tarea ${ }^{75}$.

Una exigencia señorial, poco estudiada por la historiografía gallega, pero no por ello exenta de presencia documental, es la que hace referencia a la sujeción del vasallo a la tierra. El instrumento propiciatorio de tal imposición es el propio foro, que como ya se apuntó, constituye el vehículo más adecuado para la transmisión y extensión de las obligaciones señoriales originarias de los cotos al resto del campesinado. Es bien sabido, que uno de los mayores objetivos de los rectores del señorío está vinculado con el interés que manifestaban los mismos, por mantener unos moradores estables en el seno de los núcleos de población y explotación ${ }^{76}$. Este propósito, subyacía en las cláusulas forales que impelían al campesino a morar y poblar, o hacer morar y poblar por él mismo o por otro los casales aforados ${ }^{77}$, íntimamente ligada a esta disposición, se halla la expresa prohibición impuesta al forero de enajenar el foro, sin licencia del monasterio, en beneficio de quien no comparta su condición vasallática ${ }^{78} \mathrm{o}$ inclusive, a cualquier persona que habite fuera del $\operatorname{coto}^{79}$, es decir, que el cambio de residencia del

\footnotetext{
72 José Antonio LóPEZ SABATEL, Cultivos agrícolas en la Ribeira Sacra durante los siglos XIV y $X V$, "Espacio, Tiempo y Forma". Serie III, 20 (2007), pp. 183-198/187-188.

${ }^{73}$ José Antonio LÓPEZ SABATEL, Paisaje agrario y prácticas agrícolas en la Ribeira Sacra (Galicia) durante los siglos XIV y XV, "Anuario de Estudios Medievales", 38 (2008), pp. 213-234/225.

${ }^{74}$ José Antonio LóPEZ SABATEL, Aproximación al suelo habitable en la Ribeira Sacra durante los siglos XIV y XV, "Espacio, Tiempo y Forma”. Serie III, 19 (2007), pp. 293-303/ 297-303.

${ }^{75}$ ACO, Monástica, Pombeiro, núm. 4356 y 4360. Ed. M. LuCAS y P. LUCAS, El priorato benedictino de, pp. 248-249 y 250-251.

AFP., 1/74. Ed. J. I. FERNÁNDEZ DE VIANA, Colección diplomática del, pp. 102-103.

${ }^{76}$ J. A. LóPEZ, Aproximación al suelo, pp. 293-303/297.

${ }^{77}$ AHN, Sección clero, Carpeta 1206, $\mathrm{n}^{\circ} 7$.

ACO, Monástica, Pombeiro, núm. 3186. Ed. M. LuCAS y P. LuCAS, El priorato benedictino de, pp. 117-118.

${ }^{78} \mathrm{M}^{\mathrm{a}} \mathrm{L}$. Ríos, As orixes do foro, p. 230.

${ }^{79}$ ASVM, Carpeta 4, $\mathrm{n}^{\circ} 7$.
} 
dependiente, solamente es posible, siempre y cuando esta libertad de movimientos no suponga un perjuicio para el señor en relación con sus derechos sobre los hombres y la tierra $^{80}$, de este modo, los señores se garantizan que los núcleos de población y explotación, con indiferencia de quien sea el vasallo, siempre estén habitados y explotados, sin peligro de que se reduzca así su capacidad generadora de renta fiscal. Paralelamente a esta tendencia monástica se encamina otra estipulación, por medio de la fórmula nen tomaredes amadego de ninguno, dirigida a impedir que el forero criase descendientes de hidalgos a cambio de la supresión de determinadas cargas fiscales. El amádigo, al igual que sucedió con la profiliación, suponía la admisión de un extraño procedente de un grupo social superior en el seno de una familia campesina, y de este modo, facultar su participación en la herencia como un miembro mas de la misma. Esta institución típicamente galaico-portuguesa, y de aquí su proscripción en la documentación foral, llegó a constituir una excelente plataforma de ascenso social de la hidalguía, al favorecer la extensión de sus relaciones de vasallaje a expensas del dominio señorial monástico ${ }^{81}$. Por otro lado, la sujeción a la tierra, no sólo se limitaría a satisfacer la ocupación efectiva y permanente del suelo junto con la reproducción a largo plazo de una renta, con independencia de quién fuese el vasallo capacitado para tal fin, en ocasiones, la prohibición de abandonar el coto monástico sin licencia es explícita, y su trasgresión, conlleva la invalidez del contrato foral, habilitando al monasterio para llegar un acuerdo con otro forero que sí esté dispuesto a cumplir tal condición ${ }^{82}$. Esta disposición, aproxima a algunos de los campesinos residentes en los cotos, a una situación similar a la que sufrían los payeses catalanes sujetos a la condición de remensa, puesto que con dicho término, no sólo se designa el hecho de que una persona no pueda moverse, sin pagar un rescate del predio donde trabaja y vive, sino que además, significa la imposibilidad de cualquier tipo de movilidad si así lo establece su señor ${ }^{83}$. Por otro lado, y tal como se desprende de un foro suscrito por el monasterio de San Vicente de Pombeiro, aunque la primera voz quedase adscrita al dominio señorial, el monasterio abre la posibilidad de dos líneas de actuación en relación con los herederos a la muerte del padre: la primera, que éstos sigan habitando el coto, con lo que estarían sujetos a la renta territorial pero exentos de los llamados foros miúdos, la segunda, que trabajen heredades fuera del coto, situación en la que dicha dispensa no se contemplaría, por lo que quedarían sometidos al pago de dicha detracción como testimonio de reconocimiento de señorío ${ }^{84}$. Por lo que se puede colegir, si bien el pago de un rescate señorial no se contempla explícitamente como precepto liberador de la adscripción de la tierra, tal como sucedía en Cataluña o incluso en Castilla y León ${ }^{85}$, es del todo plausible afirmar que el espíritu de la norma prevalece ya que, en este caso, no sólo la movilidad del campesinado resulta onerosa en beneficio del señor

${ }^{80}$ José Luis MARTín, ¿Campesinos de remensa en Castilla y León? (siglos XII y XIII), "En la España Medieval”, 3 (1982), pp. 37-48/39, 31 y 45.

${ }^{81}$ José Antonio LÓPEZ SABATEL, Resistencias parciales y abiertas: conflicto de clases en el medio rural gallego (siglos XIII y XV), "Estudios humanísticos. Historia", 7 (2008), pp. 103-137/135.

82 “...et demais se vos o dito Martino ou a dita vossa muller o perssona vos fordes morar fora do dito couto de Doade san nosa liçençia que este foro todo seia vago en nosas maos et que nos o dito don abbade et convento posamos del proveer a quen por ben tevernos sen pena ningua...", ASVM, Carpeta $1, \mathrm{n}^{\text {os }} 7$ y 26 ; Carpeta $4, \mathrm{n}^{\circ} 13$.

${ }^{83}$ Assumpta SERRA I ClOTA, Economía y sociedad a lo largo del siglo XIV en la Cataluña Central: efectos de la peste negra en Señorío y feudalismo en la Península Ibérica, (E. SARASA y E. SERrAnO, Eds.), v. 3, pp. 449-472/460.

84 "...e se os ditos herdeiros labraren outras herdades, que non sejan deste dito lugar, que paguen os foros miudos ao dito moesteiro, e non sejan quitos, salvo o que morar o dito lugar..." AHPO, Pergaminos, Pombeiro, núm. 20. Ed. M. LuCAS y P. LuCAS, El priorato benedictino de, pp. 218-219.

${ }^{85}$ J. L. MARTín, ¿Campesinos de remensa, pp. 37-48/38-39. 
sino que además, éste consigue que el alejamiento del vasallo no suponga una mengua de su dominio sobre los hombres aún al margen del ámbito meramente territorial.

En el campo de las rentas señoriales propias de la documentación foral, destaca la derechura o foro como detracción estrechamente identificada con la sumisión del forero al dominio señorial ${ }^{86}$. En un principio, con el término foro se designaría al conjunto de rentas que recibe el señor propietario, tanto como resultado de la cesión del dominio útil como en reconocimiento de señorío, es por ello que, tal como acontecía en León, en Galicia se puedan establecer ciertas similitudes entre esta figura jurídica y la infurción castellana, al ser ambas instituciones máximas expresiones de dependencia territorial y señorial $^{87}$. En este sentido, para la mayoría de los autores, la infurción no sería más que el pago por el reconocimiento del dominio eminente del suelo que satisface el cultivador de tierra ajena o el que habita el solar del señor ${ }^{88}$. Es más, a partir de la recepción del derecho común, se empezaría a dar el nombre de infurción a los censos que el poseedor del dominio útil ha de pagar a su señor. En consecuencia, a este proceso de asimilación terminológica, no sería ajena la voz foro, en la mayoría de los casos idéntica a la de infurción, desarrollándose una unificación semántica que llegaría a completarse en el siglo XVI ${ }^{89}$.

No sería hasta el siglo XIII, y bajo una coyuntura tendente a incrementar el poder jurisdiccional sobre los dependientes, cuando se empiece a diferenciar dentro del contrato foral, una renta recognoscitiva de dicho poder también denominada foro o derechura ${ }^{90}$. Conforme a su originaria doble naturaleza territorial y señorial, esta renta aparece en la documentación bajo su formulación más característica, también conocida por la denominación de foros miúdos, y consistente en gravar aquellos espacios agrícolas, en la mayoría de los casos huertos, cortiñas, árboles frutales, linares y nabales, que se ven excluidos del pago de la renta principal proporcional de la cosecha, y sujetos a una renta fiscal estipulada en pequeñas cantidades en metálico, o en la entrega de especies agrícolas y ganaderas ajenas a la explotación directa de dichos terrenos ${ }^{91}$. Se trata en suma, de una renta de reconocimiento señorial, propiciada por el interés de los rectores monásticos de reafirmar sus derechos sobre aquellos dominios excluidos de la documentación como generadores de la renta propietaria principal ${ }^{92}$. Disposición de los señores, que como más arriba se señaló, no sólo se circunscribe al dominio sobre la tierra, sino que también se orienta a consolidar el dominio sobre los hombres, al anular la exención en el pago de foros miúdos a aquellas voces que trabajen heredades fuera del coto monástico. Estas exigencias, pese a su escaso valor económico supondrían una considerable carga sobre las espaldas del campesinado, su carácter señorial y extraeconómico haría de dichas exacciones, al margen del bien aforado, una obligación que el campesinado no tendría más remedio que asumir criando unos determinados animales para ser entregados, según discreción del señor en fechas concretas, con independencia

\footnotetext{
${ }^{86}$ Adolfo FERnÁndez Fernández, O Mosteiro femenino de San Miguel de Bóveda na Idade Media. Estudo histórico e colección documental (séculos XII-XV), A Coruña, 2005, p. 45.

${ }^{87}$ José Antonio SEBASTIÁN AMARILlA, Del "fuero" al arrendamiento. Tenencia y explotación de la tierra en León entre la Edad Media y la Edad Moderna, "Revista de Historia Económica", 17 (1999), pp. 305-341/313.

${ }^{88}$ Remedios MORÁn MARTín, Naturaleza jurídica de la infurción, I: Concepto y evolución, "Boletín de la Facultad de Derecho de la UNED”, 2 (1992), pp. 77-108/96.

${ }^{89}$ Remedios MORÁn MARTín, Naturaleza jurídica de la infurción, II: Figuras afines y evolución hasta el siglo XVI, "Boletín de la Facultad de Derecho de la UNED", 3 (1993), pp. 153-199/177-182.

${ }^{90} \mathrm{M}^{\mathrm{a}} \mathrm{L}$. Ríos, As orixes do foro, pp. 142-145.

${ }^{91}$ J. A. LÓPEZ, Cultivos agrícolas en la, pp. 183-198/196-197.

${ }^{92} \mathrm{M}^{\mathrm{a}} \mathrm{L}$. Ríos, As orixes do foro, pp. 85 y 146.
} 
de la adaptación de la crianza al medio de la explotación cedida y a su coste de producción ${ }^{93}$. Además de la fórmula por orta e lino e naual e froyta, la derechura se paga bajo el enunciado por todalas outras cosas que Deus y der, o simplemente de renda, en unos días determinados al año dependiendo de cada monasterio. Así, en lo que respecta tanto a Santa María de Ferreira como a San Vicente del Pino, la fecha más común es el día de San Martín, mientras en San Vicente de Pombeiro los días elegidos con más frecuencia son lo que corresponden a San Vicente y San Andrés. Al igual de lo que sucedía con la renta proporcional de la cosecha, y como más adelante se verá, con el pago de la luctuosa, es común observar, sobre todo en lo que se refiere a la documentación de San Vicente de Pombeiro, un incremento de acuerdo con la sucesión de voces, de la renta en dinero como pago de la derechura, siendo las últimas las que más cantidad hayan de satisfacer. Es posible, que este proceder venga determinado ante la toma de conciencia de una más que probable depreciación de la moneda en una época de continuas devaluaciones, pero también esta línea de actuación hay que situarla en el contexto de una política monástica, orientada a endurecer las rentas señoriales como contraprestación a la tendencia generalizada en el interior de la Galicia meridional del siglo XV, consistente en suavizar las exacciones derivadas de la propiedad de la tierra ${ }^{94}$.

Quizá la renta señorial más peculiar de tierras gallegas sea la luctuosa, una tasa relacionada con la intervención señorial en las sucesiones, que consistía en el derecho del señor a cobrar un canon tras la muerte del forero titular con el fin de que pudiera heredar el foro su o sus sucesores ${ }^{95}$. Una institución de origen indoeuropeo, existente en Galicia seguramente desde antes de la Edad del Hierro, que en sus comienzos se articulaba como una indemnización que recibía el hombre libre propietario al verse privado de los servicios, en caso de muerte, de alguno de sus vasallos ${ }^{96}$. Esta detracción, al igual que sucedía con el nuncio en Castilla, es predominantemente monetaria, puesto que solamente en una ocasión, y en el tardío año de 1481, se exige el pago de una pieza de ganado, quizá reminiscencia de la forma más antigua de la carga y de su doble significación como modelo de pago y como elemento de estratificación ${ }^{97}$. En todos los casos en los que aparece la luctuosa, los bienes aforados son constituidos por unidades de poblamiento y explotación (lugares, casales o casares), y en función del valor de estos espacios y de la condición del receptor del foro, se determinaría la cuantía del canon a satisfacer. Dicho importe compone un amplio abanico que va desde los cien maravedíes por la transmisión del foro de tres lugares ${ }^{98}$, a los dos sueldos que se reclaman por un solo lugar ${ }^{99}$. Esta tasa, con relativa frecuencia, al igual que sucedía con la derechura, estaría sujeta a un incremento proporcional al orden de las voces que se sucediesen en el foro. En cuanto al número de menciones correspondientes a la luctuosa, en el seno de la documentación monástica de este territorio, se puede deducir una importancia de esta carga sucesoria no demasiado reveladora. De este modo, la presencia de dicho canon se establece en el 16,90\%, 13,71\% y 7,80\% de todos los foros, entre los siglos XIII y XV, de las colecciones diplomáticas de San Vi-

${ }^{93}$ M C. SÁNChEZ, El Bajo Miño en, p. 149.

${ }^{94}$ E. ÁlvareZ, Las exigencias señoriales en, pp. 117-152/130.

95 “...et dardes loytosa cada un de uso quando morrer ao dito moesteiro..." AHPO, Pergaminos, Pombeiro, núm. 6. Ed. M. LUCAS y P. LUCAS, El priorato benedictino de, pp. 89-90.

${ }^{96}$ Andrés PENA GRAÑA, Galicia, cuna de los celtas de la Europa Atlántica, "Anuario brigantino", 30 (2007), pp. 57-88/64.

${ }^{97}$ Julián Clemente RAMOS, Mañería y nuncio en el Becerro de las Behetrías, "Norba. Revista de historia", 7 (1986), pp. 71-80/74 y 79.

${ }^{98}$ AHN, Sección clero, Carpeta 1199, no 3.

${ }^{99}$ AHN, Sección clero, Carpeta 1199, nº 20. 
cente del Pino, Santa María de Ferreira y San Vicente de Pombeiro respectivamente. Porcentajes que se sitúan en la misma tónica para el mismo periodo, en relación con las exigencias de algunos monasterios próximos enclavados en el marco de la Ribeira Sacra (San Salvador de Chantada 14\%, San Pedro de Rocas 10\%), pero totalmente alejados de las proporciones de otros situados en la misma área geográfica (Santa Cristina de Ribas de Sil 67\%, San Esteban de Ribas de Sil 32\% ${ }^{100}$. Un último punto digno de destacar, es el sentimiento de odio que albergaba el campesinado gallego debido al el pago de la luctuosa, sentimiento que colocaría a esta exacción en el epicentro de la conflictividad social del siglo XV. Esta coyuntura queda demostrada en la negativa en 1434 de los foreros del obispado de Tuy a pagar al cabildo la luctuosa declarándose en rebeldía ${ }^{101}$, reproduciéndose la misma negativa, ya en pleno levantamiento irmandiño, esta vez a cargo de los dependientes del monasterio de Sobrado ${ }^{102}$.

\section{CONCLUSIONES}

La renta feudal, formulada en el marco de los contratos forales entendidos éstos como la pretensión señorial de extender sus derechos trascendiendo los límites originarios del coto, se articula no sólo por medio de la satisfacción de una cantidad de carácter económico y compensatoria de la cesión del dominio útil, sino también por la exigencia de ciertos derechos y servicios en reconocimiento del señorío que ha de manifestar el vasallo ante su señor. Al igual que sucede en otras latitudes de la geografía gallega, es evidente una relevancia de la renta en especie, sea ésta determinada por una cantidad fija o proporcional de la cosecha. Sin embargo, la evolución de este último tipo de exacción exhibe una progresión descendente en beneficio de la reclamación de una renta fija, coyuntura válida para las dos centurias bajomedievales en lo que respecta a Santa María de Ferreira y San Vicente del Pino y sólo observable en San Vicente de Pombeiro a partir de la primera mitad del siglo XV. En cuanto a la renta en dinero, los niveles de exigencia de estos tres monasterios hasta los inicios de la segunda mitad del siglo XIV muestran un incremento persistente, si bien en la documentación de Santa María de Ferreira esta tendencia se mantiene hasta el fin del periodo estudiado, en la de los otros dos cenobios, sufre una recesión que irá remitiendo a lo largo del siglo XV. Una peculariedad significativa de este espacio geográfico, en relación con la renta en numerario, responde a la inclinación por los rectores monásticos de fijar rentas de media o larga duración, contraviniendo la predisposición comúnmente aceptada en otros territorios consistente en estipular de corta duración o vitalicios aquellos foros de mediados del siglo XIV cuyas rentas se hubiesen de satisfacer en moneda. Otra particularidad corresponde a la generalización en los subforos del pago de una renta fija en especie en detrimento del numerario más usual en otras latitudes. En cuanto a la distribución y la evolución temporal de las rentas, se puede observar una propensión a una imposición más onerosa a partir de mediados del siglo XIV que se irá suavizando a medida que avanza la centuria posterior. No obstante, esta liviandad de los niveles de detracción con el fin de fijar al campesinado en las tierras de labor, tiene su contrapartida en la proliferación de exigencias derivadas del reconocimiento de señorío como sernas, servicios, colleitas, conduchos, yantares, posadas, derechuras, luctuosas y todas aquellas mejoras que en forma de prestación debe

\footnotetext{
${ }^{100}$ Reyna PASTOR De TOGNeri et al., Poder monástico y grupos domésticos en la Galicia foral (siglos XIII-XV). La Casa. La Comunidad, Madrid, 1990, pp. 206-207.

${ }^{101}$ C. A. DEAÑo, Rivadavia y su comarca, p. 151.

${ }^{102}$ Isabel BECEIRO PITA, La rebelión irmandiña, Madrid, 1977, p. 151.
} 
introducir el forero en el bien aforado. Requerimientos que no sólo alteraban la vida cotidiana del campesinado sino que consumían los escasos excedentes que poseía. De hecho, una vez satisfecho el montante de la renta feudal, el campesino debería restar el $20 \%$ dedicado a simiente para el año siguiente, por lo que apenas le quedaría un $30 \%$ para el autoconsumo ${ }^{103}$. Por otro lado, la valoración de las rentas percibidas y su cuantificación final, es tarea imposible de alcanzar al sólo disponer de datos cualitativos, careciendo de la información necesaria para conocer la superficie de cada una de las unidades de producción aforadas, y en consecuencia, la producción media por unidad de superficie.

Fecha de recepción del artículo: Febrero 2010

Fecha de aceptación y versión final: Mayo 2010

${ }^{103}$ Robert FossIER, Historia del campesinado en el Occidente medieval, Barcelona, 1985, p. 145. 